\title{
Por uma lista de projetos e obras de Oscar Niemeyer: Uma compilação de seu trabalho Pré-Brasília (1934 - 1957)
}

\author{
Towards a list of Oscar Niemeyer projects and buildings: a compillation of \\ his work before Brasília (1934 - 1957)
}

\author{
Rolando Piccolo Figueiredo*
}

\begin{abstract}
*Mechanical Enginee-ring (MEng) pela University of Bath, 2013; Graduando em Arquitetura e Urbanismo pela Faculdade de Arquitetura e Urbanismo da Universidade Presbiteriana Mackenzie (FAU-UPM), 2016.
\end{abstract}

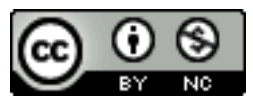

Recebido: $25 / 04 / 2020$

Aceito: $16 / 06 / 2020$

https://doi.org/10.37916/arq.urb.v28i.425

\section{Resumo}

Apesar da visibilidade e relevância da obra do arquiteto Oscar Niemeyer $(1907$ - 2012), existe uma carência de lista detalhada que apresente sistematicamente seus projetos e obras. As tentativas anteriores, incompletas, não oferecem suporte adequado àqueles que buscam informações sobre ampla produção. Este texto embasa a criação de uma lista parcial de trabalhos do arquiteto, com recorte definido entre seu primeiro projeto conhecido (1934) e o início de seu envolvimento com Brasília, em 1957. A partir de uma pesquisa junto à hemeroteca digital da Biblioteca Nacional, vários projetos inéditos são apresentados e discutidos, juntamente com outros pouco conhecidos e nunca inclusos da lista da Fundação Oscar Niemeyer (FON). Em decorrência da complexa atribuição de autoria a certas obras, resultante da forma de trabalho do arquiteto, foi decidido por também criar uma lista anexa de forma a registar casos suspeitos, duvidosos ou mesmo com sabido pouco envolvimento de Oscar Niemeyer. O resultado obtido, embora não completo mesmo dentro do recorte proposto, reúne grande número de dados que permite mais claras análises quantitativas e temporais, tal como novas percepções a respeito de parcelas específicas de seu trabalho, como o caso do Centro Técnico de Aeronáutica, e do mercado imobiliário do Rio de Janeiro.

Palavras-chave: Oscar Niemeyer. História da arquitetura. Arquitetura moderna.

\section{Abstract}

Despite the visibility and relevance of the work of architect Oscar Niemeyer $(1907$ - 2012), there is still a lack of a comprehensive list of his projects and buildings. The previous attempts, incomplete and inconsistent, do not offer proper support to those who research such a vast body of work. This text substantiates the creation of a partial list, starting with his first known project from 1934 and ends with his involvement with the construction of Brasilia, in 1957. Due to a research carried via the digital archives of the Biblioteca Nacional, several unknown projects are presented and discussed, as are lesser known projects and buildings that have never been featured on the list of the Oscar Niemeyer Foundation. It was decided to also create an annex list to compile doubtful works, works with scarce documentation and known cases of little involvement of the architect. The result, though incomplete even within its chronological limits, gathers a large quantity of data, allowing for clearer quantitative and temporal analysis, as well as new perceptions regarding specific parts of his works, as is the case of the Centro Técnico de Aeronáutica (Aeronautics Training Center) and the property market of Rio de Janeiro.

Keywords: Oscar Niemeyer. History of architecture. Unknown projects. 


\section{Introdução}

D e maneira condizente com sua posição de mais afamado arquiteto brasileiro, a obra de Oscar Niemeyer (1907-2012) é objeto de estudo para diversos pesquisadores nacionais e internacionais. Seus projetos e obras são exemplos pioneiros e seminais da arquitetura moderna brasileira, configurando um instigante campo de pesquisa. O reconhecimento aprofundado dessa obra também cumpre um papel fundamental no embasamento bibliográfico da formação acadêmica e profissional dos arquitetos, brasileiros ou não.

Ainda que a importância das pesquisas acerca do trabalho de Oscar Niemeyer possa ser considerada evidente, é frequente que os textos sobre seu legado sejam reiterativos, debruçando-se sobre umas mesmas obras, embora importantes e reconhecidas. O que, à primeira vista, pareça uma área já saturada, se mostra surpreendentemente incompleta e com importantes lacunas, visto que diversas obras, amplamente publicadas no Brasil e no exterior, ainda carecem de estudos dedicados. Ou- tra dura constatação desta incompletude é a inexistência de uma lista de obras do arquiteto bem embasada e a par das pesquisas recentes, o que este artigo procura iniciar.

Com uma vida profissional excepcionalmente longa e fortuita, Oscar Niemeyer deixou um legado muito amplo que se apresenta como um desafio particularmente complexo em relação ao trabalho proposto. A prolífica produção de sete décadas do século $X X$ e duas do XXI, o que em si já dificulta a tarefa, seu modo de fazer arquitetura exige ampla compreensão para que seja possível aferir seu nível de envolvimento em algumas obras, fato que chega a impor limites a questões autorais.

\section{Recorte}

Desta forma, decidiu-se por iniciar a lista justamente pelas primeiras obras do arquiteto. Configurando um grupo de objetos de estudos mais consolidado pela historiografia, estes projetos e obras também são os mais importantes e influentes quando com- 
preendidos dentro da produção moderna brasileira - aquela que, a partir do edifício sede da Associação Brasileira de Imprensa (1935 - 1941), dos irmãos Roberto, e do Ministério da Educação e Saúde Pública (MESP) (1936 - 1945), é primeiramente lançada ao mundo através da exposição e respectivo catálogo Brazil Builds (GOODWIN e SMITH, 1943).

Se a lista aqui apresentada tem início óbvio - o primeiro projeto conhecido de Niemeyer, datado de 1934 - seu fim, com os primeiros projetos definitivos de Brasília em 1957, é uma escolha que se justifica por duas razões: a primeira, sua proximidade com essa parcela da obra do arquiteto que permite uma análise crítica melhor embasada, e a segunda, a vasta e célere produção ocasionada pelo início dos trabalhos da nova capital que exigiria imensa dedicação e proximidade às fontes primárias para ser estudada com a minúcia que aqui se propõe.

É importante destacar, por fim, que a lista se trata do trabalho arquitetônico de Niemeyer, incluindo-se projetos e obras da arquitetura, urbanismo, cenografia e mesmo expografia, mas excluindo-se sua produção de mobiliário, gravuras e esculturas, por exemplo.

\section{Listas existentes}

Dizer que uma lista completa de obras de Oscar Niemeyer não existe, não significa que o assunto não tenha sido abordado. Em 1996, o arquiteto Josep Maria Botey lança seu livro Oscar Niemeyer: obra y projectos (BOTEY, 1996), no qual busca apresentar a totalidade do trabalho do arquiteto. As obras, agrupadas em temas (residências, obras particulares, edifícios multifamiliares, edifícios públicos e institucionais, edifícios religiosos etc.), cobrem toda a carreira de Niemeyer até aquele ano. No entanto, apesar de a proposta de ser um catálogo integral, surpreendem claras omissões como projetos publicados nas duas primeiras monografias sobre $O$ arquiteto: os dois livros de Stamo Papadaki (PAPADAKI, 1950, 1956). Apenas para citar dois exemplos, não aparecem no livro quaisquer menções aos projetos do Centro de Lazer da Lagoa (1945) ou da Residência Leonel Miranda (1953).

Além destas lacunas, é possível questionar o método de inclusão de projetos individuais em cada categoria. Se a urbanização da Pampulha é incluída como projeto de 1940 sob 'urbanismo', não se encontra listado o projeto urbano mais sofisticado do Centro Técnico de Aeronáutica, de 1947. Sobre esta obra, apenas a arquitetura é citada sob 'edifícios públicos e institucionais' mesmo que esta contemple residências unifamiliares, escolas e mesmo uma capela, de modo articulado no espaço. 
A superficialidade com a qual grandes projetos são tratados no livro de Botey se repete na outra lista que busca apresentar o trabalho completo de Oscar Niemeyer. Disponibilizada através de um arquivo PDF pela Fundação Oscar Niemeyer (FON), o documento intitulado 'Relação em ordem cronológica das obras do arquiteto, segundo informações da Fundação Oscar Niemeyer' (FON, s.d.), é o documento mais completo encontrado pelo autor embora também não esteja atualizado em relação às pesquisas vigentes. Não obstante, este foi utilizado como base para elaboração da lista apresentada, sendo as inserções, decorrentes de diferentes fontes, tal como considerações pormenorizadas.

\section{Método}

Contribuindo para um olhar patrimonial do legado de Oscar Niemeyer, foram considerados como itens individuais, cada projeto e obra construída. Deste modo, anteprojetos que sofreram alterações significativas ante execução são listados como projeto não construídos, enquanto cada edificação, como obra executada. Já no caso de projetos que envolvem mais de um edifício, estes são inclusos individualmente, tornando mais claro o escopo de atuação do arquiteto.

Como mencionado anteriormente, o documento da FON foi o ponto de partida da relação de obras, sendo que algumas questões foram corrigidas, ou- tros projetos e obras esmiuçados em suas complexidades, e vários acrescentados. Para além da pesquisa acadêmica atual que já identificou diversos exemplares da arquitetura de Oscar Niemeyer, este artigo traz vários projetos inéditos. A maioria destes foi descoberto através de uma pesquisa realizada na hemeroteca digital da Biblioteca Nacional pelo verbete 'Niemeyer', entre os anos de 1930 e 1960. Foram consultados os seguintes jornais: Correio da Manhã, Diário de Notícias, O Cruzeiro, O Jornal, Correio Paulistano, Diário Carioca, Diário da Noite, Diário de Pernambuco, A Manhã, A Noite, Gazeta de Notícias, Jornal de Notícias, Jornal do Brasil, Jornal do Comércio, O Dia (PR), O Globo Esportivo, O Imparcial (RJ) O Radical (RJ), Última Hora e o Tribuna Popular. Também foram consultadas as revistas Manchete, Rio, Shell, Sombra, A Casa, Brasil, Carioca, Fon Fon, llustração Brasileira, Letras e Artes, O Mundo llustrado, Para Todos, Revista da Semana, Vamos Ler e Vida Doméstica.

Durante a pesquisa, foi constatada a atribuição de autoria a Oscar Niemeyer de diversos projetos inéditos, nunca mencionados em quaisquer fontes previamente conhecidas pelo autor. Estes serão discutidos individualmente, mas a maioria foi incluída nesta versão da lista por duas razões: primeiramente, tratando-se de jornais de grande circulação, é improvável que a menção ao arquiteto nas matérias passasse desapercebida. Valendo-se do exemplo do restaurante drive-in Bom Voyage que, de acordo com Carlos Lemos (LEAL, 2003), fora projetado por 
Gauss Estelita, porém publicado na revista Acrópole como projeto de Oscar Niemeyer, a ampla disponibilidade da informação não contestada de autoria à época é suficiente para pressupor uma participação profissional majoritária no desenvolvimento dos projetos. Em segundo lugar, ao publicar pela primeira vez tais trabalhos, abre-se a possibilidade de outros pesquisadores investigarem mais a fundo cada situação, não sendo negada a possibilidade de exclusão da lista. Para além da lista principal, optou-se por também criar uma lista anexa contendo aqueles projetos e obras que não representam, de forma categórica, características ou evidências de se trataram de trabalho criativo de Oscar Niemeyer. Entre as razões de inclusão nesta lista, incluem-se ligeiro envolvimento do arquiteto em etapas iniciais de projeto, menções únicas a projetos que possivelmente nem chegaram a ser iniciados e, sobretudo, projetos cuja existência não pode ser comprovada por fontes documentais.

Sobre a apresentação dos itens da lista, foi adotado um sistema cronológico no qual se prioriza o ano de projeto frente ao fim de construção. Ao mesmo tempo que isto facilita a compreensão da evolução de sua arquitetura por melhor localizar temporalmente obras de longa execução, por outro lado acarreta em posições imprecisas daquelas obras sobre as quais é sabido apenas o ano de conclusão - outro fator que caracteriza este trabaIho como aberto. Ademais, para obras do mesmo ano, quando não havia informação disponível a respeito dos respectivos meses de trabalho, a ordem da FON foi mantida, sendo os projetos inéditos adicionados após os já conhecidos. Revisões substanciais que geram diferentes versões do mesmo projeto são assim identificados, enquanto reformulações mais abrangentes rendem a denominação de novo projeto.

Vale aqui destacar também que, embora nenhuma obra tenha sido removida da lista da FON, na discussão a seguir, certas obras comumente atribuídas ao arquiteto têm sua autoria refutada por este autor, sendo cada decisão propriamente explicada e embasada. Abaixo, seguem as considerações feitas a respeito dos projetos e obras menos conhecidos, estudados ou inéditos.

\section{Projetos e obras}

As listas podem ser encontradas ao fim do artigo.

O primeiro projeto conhecido de Oscar Niemeyer é - Club Sportivo, publicado na Revista da Directoria de Engenharia da Prefeitura do Districto Federal (CLUB, 1935), em 1935. Visto que a publicação é do mês de janeiro, concorda-se com Roberto Segre e José Barki (SEGRE, BARKI, 2008) ao atribuir ao projeto o ano de 1934, ao invés daquele especificado na lista da FON. 
Fora esta pequena correção, encerrando a década de 1930, existem menções a três projetos de expografia, todos de 1939, dos quais pelo menos dois foram executados. Noticiado pelo Correio Paulistano em abril de como parte das comemorações do centenário de Machado de Assis, uma 'Exposição Machadiana' deveria ser organizada no hall da Biblioteca Nacional. Sob responsabilidade do Instituto do Livro em colaboração com a diretoria da própria Biblioteca, o projeto seria executado pelo 'engenheiro Oscar Niemeyer' do Serviço do Patrimônio Histórico e Artístico (PUBLICAÇÃO, 1939).

Já em matéria do Jornal do Comércio no dia 06 de agosto, o nome de Oscar Niemeyer juntamente com Manoel Bandeira é indicado como responsável pela 'apresentação artística' do material exposto na Exposição do Livro Norte Americano Moderno (EXPOSIÇÃO, 1939a). Confirmando sua execução, a carta do embaixador dos Estados Unidos Jefferson Caffery dirigida ao ministro Gustavo Capanema foi publicada no Diário Carioca (EXPOSIÇÃO, 1939b) no dia 11 de agosto. Nela, Caffery faz 'menção especial sobre os esforços empregados pelo Dr. Augusto Meyer e o Dr. Oscar Niemeyer e seus colaboradores responsáveis pelo arranjo'.

Encerrando sua participação em expografia de livros, coube a Oscar Niemeyer e a Pedro Gouvêa Filho, a organização da exposição 'O Livro Brasileiro' em Montevideo. Em matéria do Correio da Ma- nhã de 15 de outubro de 1939 (A SEMANA, 1939)

fica estabelecida a partida da delegação brasileira no dia 17 pelo navio a vapor Pedro II, que, além dos assistentes técnicos, era constituída pelos delegados do governo Carlos Maul e Oswald Orico. Cerca de 4 mil volumes também embarcaram, cobrindo mais de 3 mil autores. A exposição, inaugurada em 15 de novembro do mesmo ano (O LIVRO, 1939), contou com um catálogo publicado pelo Serviço Gráfico do Ministério da Educação (MINISTÉRIO, 1939).

Embora não tenha sido possível determinar se a Exposição Machadiana de fato ocorreu (e, portanto, se o arquiteto chegou a projetá-la), a menção do Serviço do Patrimônio, do qual Oscar Niemeyer era funcionário, sugere-se que os outros trabalhos relacionados também têm origem naquela instituição que teria disponibilizado parte do seu corpo técnico para elaboração de projetos culturais do próprio governo. A uniformidade do material exposto, sempre livros, é intrigante, sugerindo que a especificidade da primeira oportunidade tenha ocasionado a seleção de Oscar Niemeyer para os projetos subsequentes.

Já de 1943, o projeto do Instituto de Previdência do Estado do Rio Grande do Sul (IPERS), embora já conhecido do meio acadêmico (XAVIER, MIZOGU$\mathrm{CHI}, 1987)$, nunca constou das listas de obras do arquiteto. Tratando-se de um projeto vultuoso, um de seus maiores até então, faz-se necessária uma 


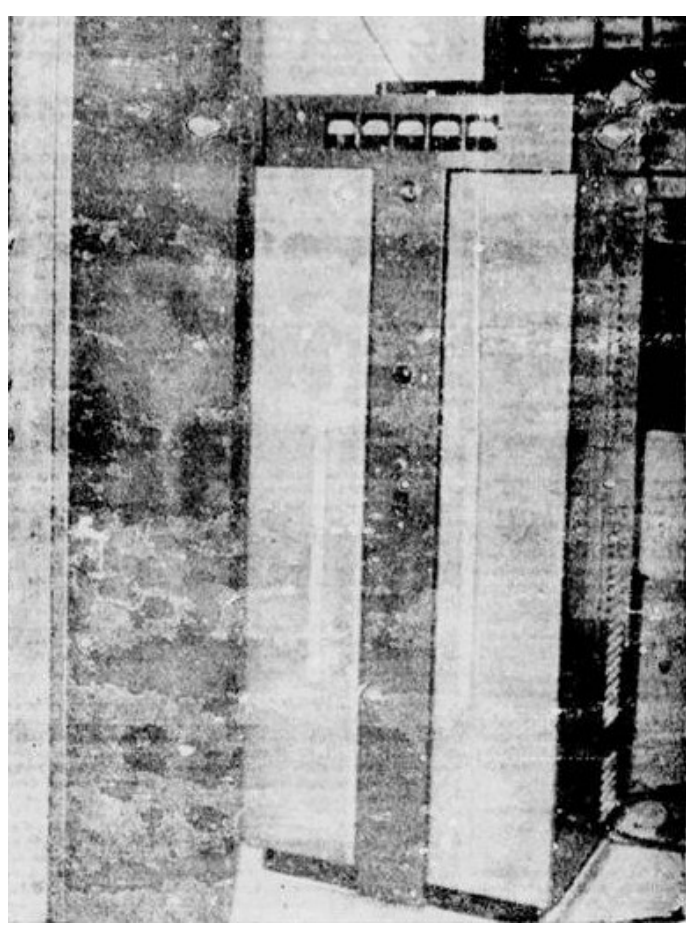

Figura 1 - Maquete da sede da Rádio Tamandaré. Fonte: ESTÚDIOS, 1951 pesquisa mais detalhada a fim de localizar seus desenhos, visto que até agora uma imagem da maquete foi publicada. De acordo com o próprio IPERS (O INSTITUTO, s.d.), dois projetos para a primeira sede da instituição haveriam sido produzidos, sendo o outro pelo arquiteto Fernando Corona. Por razão da falta de recursos ocasionada pela segunda Guerra Mundial, e posteriores mudanças no traçado das ruas lindeiras ao lote, o projeto não teria sido executado.

Outra lacuna importantíssima do trabalho de Oscar Niemeyer desse período foi descoberta pelo arquiteto e historiador Volker Welter, da Universidade da Califórnia Santa Bárbara. Em seu livro sobre o mecenato de arquitetura da família Tremaine (WELTER, 2019), a existência de um projeto revisado, menor, para a residência de praia de Burton e Emily Tremaine é comprovada a partir de duas cartas: a primeira, de Oscar Niemeyer para Alvin Shaw III (arquiteto que intermediou o projeto) datada de 3 de junho de 1948, e outra de Shaw para Emily e Burton Tremaine de 11 de junho do mesmo ano. No entanto, além destas menções, até agora não foi possível localizar quaisquer desenhos desta versão.

O primeiro projeto inédito a ser discutido é citado no jornal Diário de Pernambuco de 11 de maio de 1950 (O EDIFÍCIO, 1950), onde numa curta matéria é relatado que o projeto do edifício da Rádio Tamandaré, projeto de Oscar Niemeyer, já fora apro- vado na Prefeitura e que seria construído à Rua do Imperador Pedro II. Já em grande matéria do dia primeiro de abril de 1951 (ESTÚDIOS, 1951) é noticiada a inauguração da rádio, não em seu edifício sede, porém. Segundo o jornal, retificações determinadas pelo plano urbanístico da Prefeitura do Recife ocasionaram em alterações no alinhamento e situação de avenidas da área, modificando, portanto, o lote original. $\mathrm{O}$ 'engenheiro Oscar Niemeyer Filho' teria, então, refeito o projeto, que já estava em construção no momento da publicação. Adicionando complexidade ao caso, a Lei 951, de 31 de agosto de 1950 (RECIFE, 1950) que "assegura ao futuro edifício da Rádio Tamandaré Ltds., a ser construída à Rua do Imperador Pedro II, [...], isenção do pagamento do imposto predial [...]", o comprova que a sede, de alguma maneira, fora construída.

Para além destas informações detalhadas, é também importante a publicação de uma fotografia da maquete do projeto (figura 1) que ilustra um edifício conformado por duas barras prismáticas com empenas cega ligadas por um corpo central que no topo se estende sobre estas, conformando um $\mathrm{T}$. Cinco perfurações neste último pavimento parecem indicar espaço dedicado a algum equipamento técnico, possivelmente relacionado às transmissões.

Já que o edifício é descrito como havendo três fachadas (as adicionais voltadas para a Rua Martins de Barros e Marquês do Recife), supõe-se que a maquete seja do primeiro projeto, visto que uma 
edificação distinta, mas de características modernas, existe em tal local. Contando com pilotis, janelas em fita e um mezanino de desenho recortado, pode-se inferir que o projeto revisado ou a execução (ou ambos), tiveram menor ou nulo envolvimento do arquiteto.

Da revista francesa l'Architecture d'Aujourd'Hui de agosto de 1952 (ARCHITECTURE, 1952), dedicada à produção brasileira, consta uma perspectiva, quatro plantas e um corte de um 'Edifício da Televisão', projeto que sempre suscitou questionamentos. Com uma descrição bastante genérica, ele é creditado como a sede da 'televisão brasileira', contando com espaços administrativos, um teatro, áreas técnicas, restaurante e auditórios, não sendo especificado onde o empreendimento estaria localizado. Essa questão pôde ser esclarecida a partir de uma matéria do jornal O Dia (SERÁ, 1951), que credita co-autoria ao arquiteto Hélio Uchôa Cavalcanti (1913 - 1971).

Com uma grande imagem da perspectiva supracitada, a manchete 'será construído no Brasil o maior teatro do mundo' chama atenção para o que na verdade são dois empreendimentos de iniciativa dos Diários Associados, um no Rio de Janeiro (Taba Tupi) e outro em São Paulo (Taba Guaianazes). Sobre a edificação carioca, é conhecido um projeto de 1956 que já consta da lista da FON e que, se analisada a forma do lote (entre as ruas Camerino e Alexandre Mackenzie), percebe-se se tratar de um redesenho do projeto publicado na $\mathrm{Ar}$ chitecture d'Aujourd'Hui. Grandioso, esse foi apresentado de antemão à Getúlio Vargas na antevéspera de sua posse por Assis Chateaubriand durante almoço na casa do Senador Epitácio Pessoa, e ofereceria um programa misto: dois mil apartamentos, playgrounds, lactários, de um instituto de Nutrição Infantil além de clínicas, áreas para funcionamento da rádio - três 'gigantescos' auditórios e quinze estúdios, e ainda um restaurante popular para $10 \mathrm{mil}$ refeições diárias.

Até o momento não foi possível determinar se o paulistano Taba Guaianazes foi de fato projetado, visto que nenhuma iconografia dele foi localizada. Sabe-se apenas que, de vulto similar a seu irmão carioca, ele contaria com um teatro para 8 mil espectadores, também nomeado em homenagem ao presidente que tomaria posse naquele ano.

Com ampla publicidade no ano de 1952, outro projeto inédito cujo desconhecimento contrasta com a quantidade de menções é o Parque Residencial Fonte da Saúde (figura 2). Com diversos anúncios nos principais jornais, notadamente o Diário de Notícias e Correio da Manhã, a este empreendimento foram dedicadas matérias mesmo nas revistas Manchete e Rio.

Projetado conjuntamente com Hélio Uchôa, os 96 apartamentos conformariam um bloco de 12 anda- 


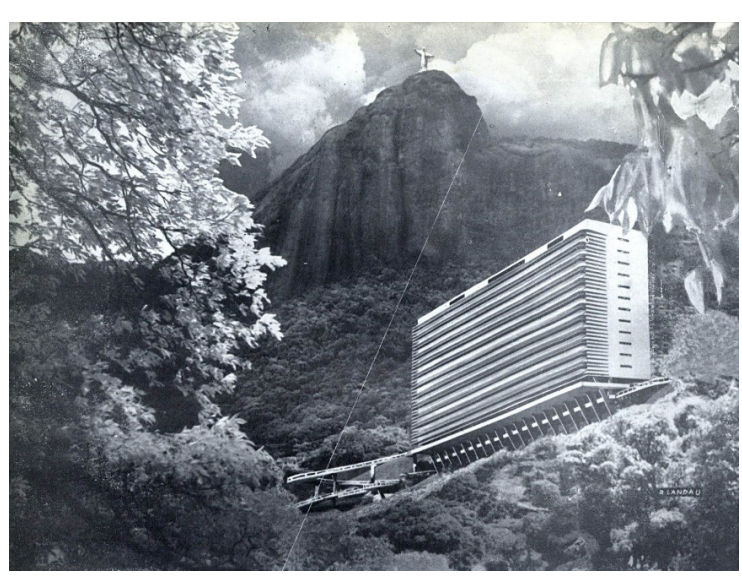

Figura 2 - Parque Residencial Fonte de Saúde. Fonte: O PROBLEMA, 1952

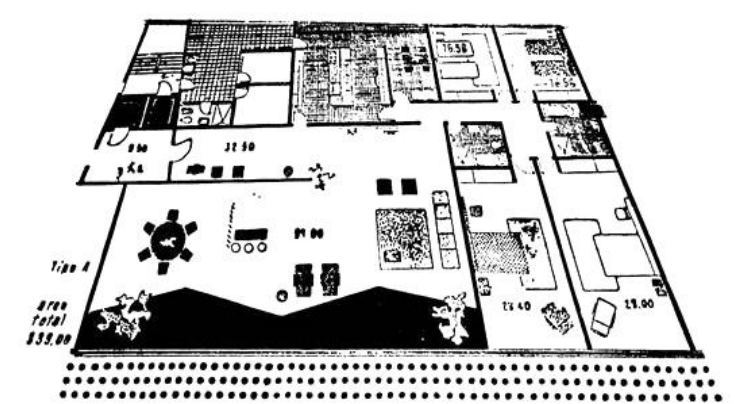

Figura 3 - Planta perspectivada do apartamento tipo A. Fonte: PARQUE, 1952 res de 136 por 15 metros, sobre pilotis e com a frente protegida por brise-soleils (três por andar). Em um terreno de 33 mil metros quadrados, o edifício contaria ainda com um salão de festas com 24 metros de comprimento no terraço, sob uma cobertura com aberturas circulares similares aquelas do Hospital Sul América (1952 - 1958). Ao lado deste, haveria um playground coberto e salão para jardim de infância, e na extremidade oposta, uma lavanderia e tinturaria e quartos para funcionários. Uma área de recreação com piscina e 'ginásio com todos os aparelhos' se localizaria próxima à ampla e sinuosa rampa de acesso de veículos (haveria garagem para 100 automóveis) (PARQUE, 1952), acessada provavelmente por um túnel.

As fotomontagens publicadas da maquete (de autoria do fotógrafo Rafael Landau) mostram um grande edifício implantado em uma encosta bastante íngreme, sendo que pilares em $\mathrm{V}$ assimétricos e transversais à barra acomodariam as diferentes projeções das lajes do térreo e da garagem. Já os brise-soleils horizontais se dobrariam nas empenas laterais, afinando-se até interrompidos. Em planta perspectivada publicada em propaganda no Diário de Notícias (figura 3), estes aparecem perfurados, algo característico do arquiteto no período, tal como um diferente material de piso utilizado próximo à janela, demarcando uma varanda.
Sobre o já citado Hospital Sul América, deste mesmo ano, vale mencionar um aspecto que foi publicado, ao que indicam as pesquisas atuais, apenas na mesma edição da revista francesa abordada anteriormente. Configura um projeto inteiro, praticamente esquecido, a torre residencial de apartamentos duplex que se localizaria logo em frente ao hospital. Se este deveria atender aos funcionários da Instituição Larragoiti, supõe-se que tais apartamentos também seriam destinados a um público similar. De maneira análoga ao hospital, o bloco (com mais pavimentos), contaria com pilotis de pilares em $\mathrm{V}$, porém com uma linha intermediária adicional de colunas, agora rotacionadas em 90 graus. Já a elevação claramente indica influência dos edifícios do Parque Guinle, projetados por Lucio Costa (1902 1998), em execução naquele momento. Com módulos praticamente quadrados, Niemeyer busca uma composição variando o fechamento entre elementos vazados, brise-soleils verticais ou janelas em fita. As áreas de lazer, que incluem não apenas o térreo do bloco de habitação como a cobertura do bloco cirúrgico (igualmente não executado) contém os mais ousados desenhos de marquises curvas do arquiteto, a par com aquela do segundo projeto para o Hotel Quitandinha (1953).

Compartilhando as varandas fechadas em elementos vazados e com janelas do Parque Guinle existe também o projeto para o conjunto João Ernesto (figura 4). Tal como o Parque Residencial Fonte da Saúde, ele foi amplamente divulgado nos jornais em 


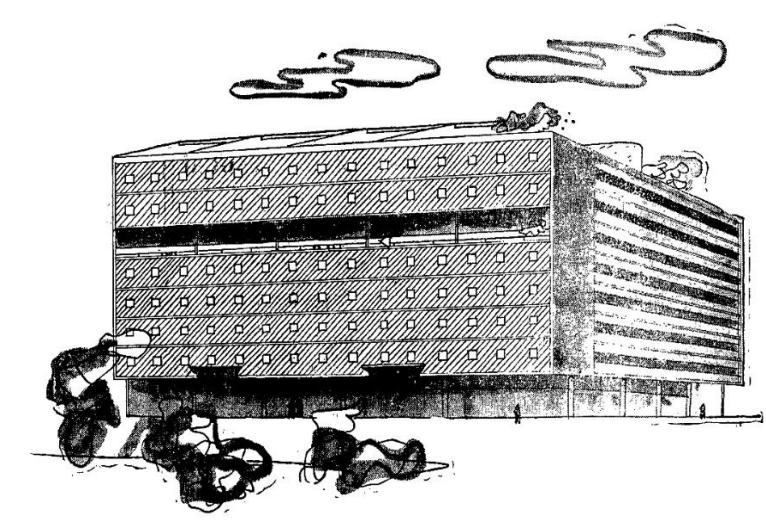

Figura 4 - Perspectiva do conjunto João Ernesto. Fonte: DO MINISTÉRIO, 1952

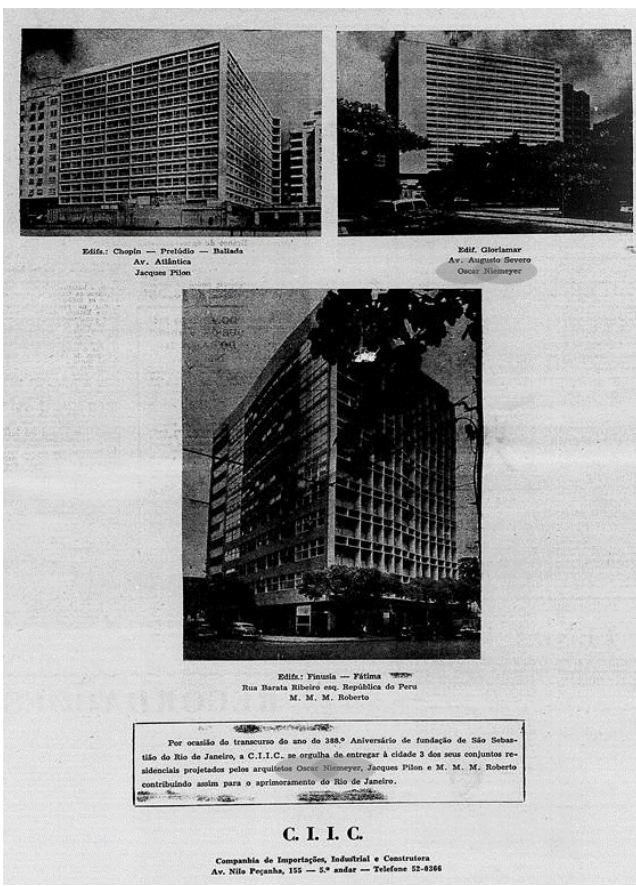

Figura 5 - Propaganda da CIIC. Fonte: CIIC, 1955 busca de compradores para o empreendimento que, além de oferecer apartamentos de diferentes tipos e tamanhos, contava com uma galeria no térreo (DO MINISTÉRIO, 1952). De modo similar aos anúncios publicitários do Banco Nacional Imobiliário (BNI), em São Paulo (LEAL, 2003), a autoria do projeto (que novamente conta com a colaboração de Hélio Uchôa), é destacada, sendo imagens do edifício do MESP e da Igreja da Pampulha incluídas como exemplos da 'técnica' e da 'arte' de Oscar Niemeyer.

Localizado em uma das esquinas de frente à praça General Osório, em Ipanema, o edifício chegou a ser construído, embora seja necessário que pesquisas mais detalhadas elucidem o grau de participação do arquiteto visto que a obra, mesmo que já alterada, parece diferir em algumas características importantes daquilo anunciado.

A partir de 1952, começam a aparecer no Correio da Manhã anúncios referentes a venda de unidades do edifício Gloriamar e Poços de Caldas (na Glória, próximo à praça Paris), nos quais o nome do arquiteto aparece como um atrativo. Adicionalmente, em 1955 publica-se uma propaganda da Companhia de Importações Industrial e Construtores (CIIC) que destaca a qualidade arquitetônica dos projetos construídos pela empresa (CIIC, 1955). Figuram os edifícios Chopin, Prelúdio e Ballade, de Jacques Pillon, o Finúsia e Fátima dos ir- mãos Roberto, e por fim o Gloriamar, supostamente de Oscar Niemeyer (figura 5).

Pesquisas iniciais nos arquivos da prefeitura não produziram resultados que pudessem confirmar esta informação, e qualidade de execução do edifício o inclui dentre aqueles que possivelmente foram desenvolvidos sem a participação do arquiteto. $O$ peso da inclusão do nome do arquiteto justamente em uma peça de publicidade certamente indica a necessidade de uma pesquisa mais aprofundada sobre este caso.

Um dos achados desta pesquisa que levantou algumas suposições foi uma imagem do projeto do Clube Botafogo (figura 6) publicada em 1952 (NIEMEYER, 1952), sendo que, de acordo com a lista da FON, ele data 1955 - 1956. Ademais, é em 1956 que se notícia que o projeto paisagístico das 'novas dependências do Botafogo de Regatas, que são projeto simples e sóbrio de Oscar Niemeyer' (BARATA, 1956a), seria executado por Carlos Perry, quem o arquiteto também teria convidado para trabalhar conjuntamente no projeto do Hansaviertel (BARATA, 1956b).

Esta sequência de informações pode levar ao entendimento que o projeto do clube, de 1951, foi executado e concluído em 1956, quando o paisagismo fora contratado. Sabe-se, no entanto, que um clube chegou a funcionar por pouco tempo na área do an- 


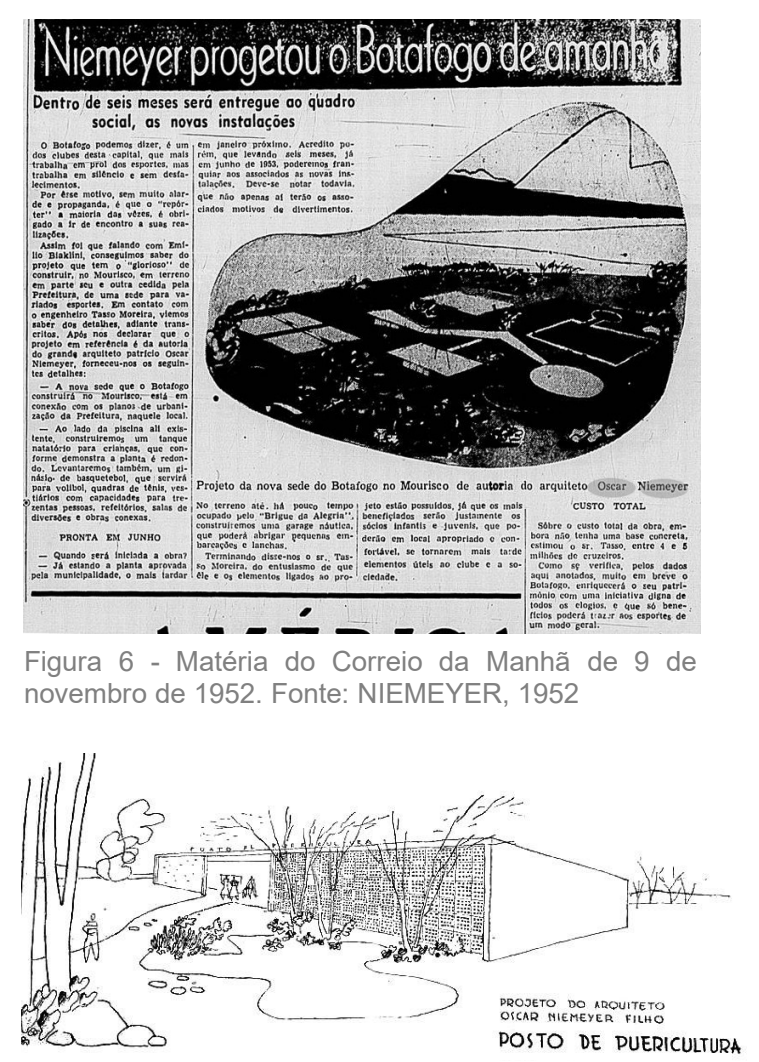

Figura 7 - Posto de Puericultura de Rancharia. Fonte: SIMONE e FRANCO, 2017

usjt • arq.urb • número 28 | maio - agosto de 2020 tigo pavilhão Mourisco (especificada na matéria do Correio da Manhã como local do empreendimento). A iconografia encontrada, porém, não concorda com o projeto publicado que previa, entre outras edificações, uma que se assemelha ao projeto não construído para o restaurante do Ibirapuera (1951). Fica, portanto, o questionamento não apenas sobre o que teria sido de fato construído, ou mesmo sobre qual projeto 'simples e sóbrio' o jornalista teria se referido - talvez o edifício do Clube Guanabara, ao lado. Como em tantos outros casos, o trajeto entre projeto e (eventual) obra lança dúvidas sobre grau de envolvimento de Oscar Niemeyer.

Tratando-se de um projeto paulista, ainda de 1952, foram duas matérias, com informações contrastantes, que levaram este autor a encontrar uma pesquisa específica sobre o posto de puericultura de Rancharia. Uma reproduz o discurso de Assis Chateaubriand no dia 9 de novembro de 1952 durante a abertura do posto de puericultura Edmundo Bittencourt CHATEAUBRIAND, 1952), enquanto em outra, na revista O Cruzeiro, (MORAES, 1957), uma foto de uma edificação aparece em matéria sobre a cidade de Oswaldo Cruz, vizinha. A imagem, no entanto, mostra um edifício sem as características da arquitetura de Oscar Niemeyer.

Ao buscar mais informações sobre esta obra, descobriu-se o artigo de Sergio de Simone e Francisco Luiz Franco (SIMONE e FRANCO, 2017), do Instituto Butantan, que além de fazer a conexão entre o arquiteto e o antigo prefeito da cidade, Francisco Franco (não confundir com o coautor do artigo), apresenta um croqui da coleção deste. Com traços característicos do arquiteto, o edifício representado, de mesma tipologia do construído, mostra um pequeno volume trapezoidal definido por uma cobertura que se dobra em empenas trapezoidais e uma elevação maior assimétrica tripartida em alvenaria, acesso e elementos vazados (figura 7). As claras diferenças entre a perspectiva e o edifício construído (e eventualmente demolido) indicam que Oscar Niemeyer pouco se envolveu além da etapa de anteprojeto, sendo isso registrado na lista de obras.

Um segundo projeto do interior, desta vez no estado de Minas Gerais, que nunca foi discutido em pesquisas acadêmicas é a Escola Normal e Ginásio Estadual de Uberaba, atualmente Escola Estadual Marechal Humberto de Alencar Castelo Branco. Projetada em 1952, teve um histórico de construção complicado que acabou por parcialmente descaracterizar sua arquitetura. Configurada por um longo bloco de um pavimento sobre pilotis, ela é bastante similar ao bloco maior do Instituto Tecnológico de Aeronáutica (1947?), inclusive na proposta de cobertura em sheds. No caso mineiro, no entanto, $\mathrm{o}$ bloco é curvo e apresenta uma abóbada como marquise de acesso, tal como uma rampa de dois lances em sua elevação posterior. O projeto contava ainda com um auditório na porção frontal do terreno, coberto também por uma grande abóbada, alinhado longitudinalmente com a rampa citada. 


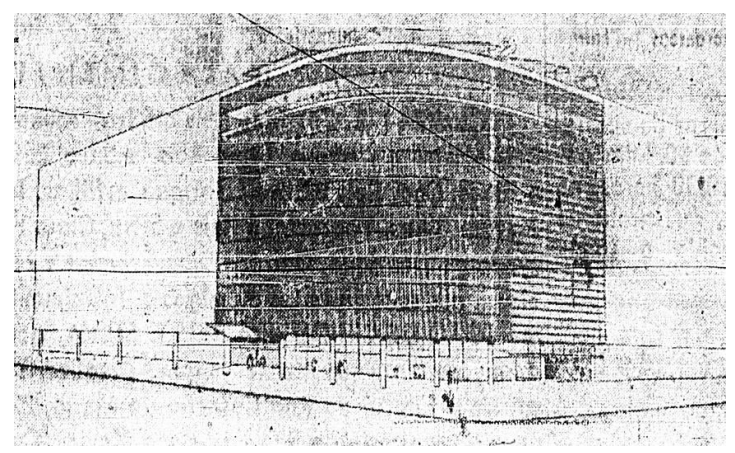

Figura 8 - Clube de Aeronáutica. Fonte: ANIVERSÁRIO, 1954
Encerrando as várias propostas de 1952, existe na prefeitura de Juiz de Fora um projeto para a rodoviária da cidade que nunca foi publicado, e tampouco incluído nas listas de obras e projetos. Se neste caso a existência dos desenhos é sabida, aquela de um suposto projeto para uma represa na cidade (aos moldes da Pampulha, sendo que seus desenhos teriam sido pessoalmente apresentados pelo arquiteto), se mantém em dúvida, visto que nunca foram encontrados (LOURES, 2013).

A próxima lacuna da lista é de 1954 e relaciona Oscar Niemeyer a outro grande arquiteto brasileiro. Por ocasião do restauro encabeçado por Fábio di Mauro da célebre residência Nadyr de Oliveira, projeto de Carlos Millan (1927 - 1964), descobriuse um projeto anterior para um lote na estrada das Canoas, no Rio de Janeiro, onde o Major Djlama Machado e sua esposa Nadyr viviam. Os seis desenhos relativos ao projeto, ainda pertencentes à família, mostram um prisma de cobertura inclinada, similar em corte à escola de Diamantina (1951 1954), implantado sobre uma plataforma com piscina que age como cobertura de uma garagem, ao nível da rua.

Outro projeto completamente inédito também data de 1954, e apenas uma perspectiva (figura 8) comprova sua existência (ANIVERSÁRIO, 1954). O Clube de Aeronáutica, fundado em 5 de agosto de 1946, já no ano seguinte estabelece como estatuto a construção de sua sede definitiva, tal como a angariação de 3 milhões de cruzeiros para sua construção.

Em linha com o tratamento usualmente dado pelo arquiteto a edifícios em malha urbana consolidada, este edifício também está de acordo com a estratégia por ele empregada a lotes de esquina, na qual a fachada curva concorda com as testadas vizinhas. Com sua localização especificada no cruzamento das ruas Graça Aranha e Santa Luzia (próximo ao edifício do MES), é possível deduzir pela variação de seus brises-soleil (que se alternam de verticais para horizontais no ponto onde a seção de curva encontra a reta) que este ocuparia o lote onde se encontra o edifício Santos Dumont atualmente. Esta composição, similar, porém de proporções invertidas com o edifício Montreal (1950 - 1953), configura todo o volume sob pilotis e sobreloja, e conta ainda com marquise de acesso, ampla varanda no penúltimo pavimento e terraço jardim.

Também com um único registro, foi descoberto um projeto para o Clube Caiçaras, na Lagoa Rodrigo de Freitas (MAURÍCIO, 1955). A foto da maquete (figura 9), publicada em 1955, mostra uma setorização racional da ilha, com uma bateria de quadras ocupando sua extensão, algumas edificações ortogonais em seu centro (possivelmente ao redor de uma grande piscina) e um grande edifício coberto por uma laje de desenho sinuoso acoplado a um volu- 


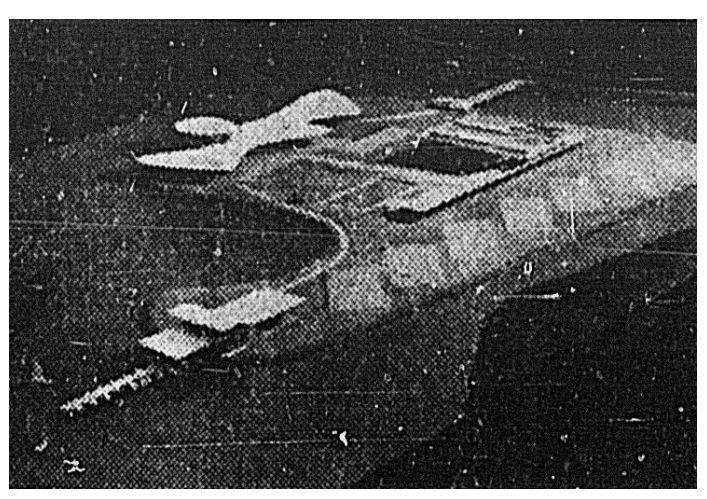

Figura 9 - Maquete do Clube Caiçaras. Fonte: MAURÍClO, 1955

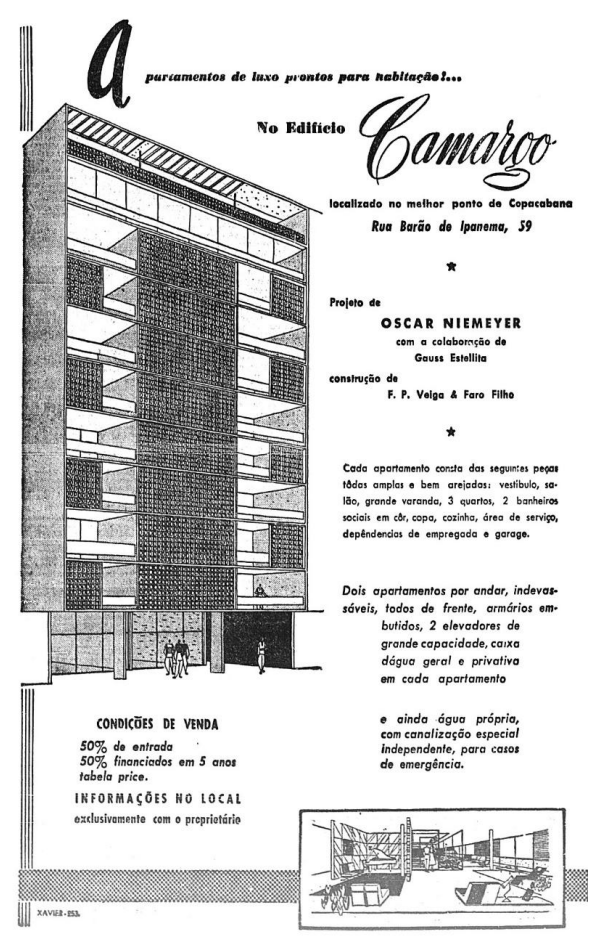

Figura 10 - Edifício Camargo. Fonte: APARTAMENTOS, 1955

usjt • arq.urb • número 28 | maio - agosto de 2020 me circular de proporções horizontais. Estranhamente, esta imagem serve apenas como um exemplo de um projeto do arquiteto em uma pequena nota que menciona o iminente regresso de Oscar Niemeyer ao Brasil, após sua viagem europeia.

De maneira similar ao conjunto João Ernesto já discutido, em 1955 se inicia ampla divulgação do edifício Camargo (figura 10) em jornais do Rio de Janeiro. Contando com a colaboração de Gauss Estelita (APARTAMENTOS, 1955), é um dos raros exemplos de obra executada para o mercado imobiliário carioca em ótimo acordo com o projeto apesar de não apresentar proporções horizontais tão generosas quanto as da perspectiva dos anúncios. O resultado é bastante feliz, sendo sua exclusão do corpo de trabalho do arquiteto justificada, possivelmente, apenas pela menor importância creditada a esse tipo de programa dispensada pelo projetista neste período (vide seus projetos para o BNI em São Paulo).

O projeto para residência $M C$, descoberto a partir do contato por parte de seus atuais proprietários, os irmãos Philipp e Matthias Lamprecht, finaliza o ano de 1955 (NIEMEYER, 1955). Localizada no morro da Babilônia, no Leme, a obra apresenta diversas características não condizentes com o trabalho do arquiteto, apesar de vários elementos típicos do período, como elementos vazados, pastiIhas e mesmo um pilar em $\mathrm{V}$ assimétrico. A apa- rência de modernismo popular do imóvel acarretou numa pronta refutação de autoria. Causando estranhamento, porém, uma cópia de uma prancha contendo a planta térrea da casa apresentava carimbo compatível com o usual do escritório de Oscar Niemeyer nesse período, mesmo se a solução arquitetônica não parecesse condizente com a qualidade de seu trabalho. Esta contradição foi resolvida após uma troca de e-mails com os proprietários, que acabaram digitalizando todo o material restante do projeto, totalizando quatro pranchas.

A primeira, MC 2 (figura 11), é a única que apresenta o projeto em sua primeira versão. De traços mais econômicos, aqui a autoria já pode ser atribuída, visto que características espúrias constantes na versão atualizada (pranchas MC 5 e MC 6, de janeiro de 1956) aqui não aparecem - um exemplo é a parede esquerda da garagem, que de um único plano estrutural se converte em uma parede em elementos vazados, porém interrompidos por um pilar de seção quadrada.

Claramente indicando uma revisão de projeto despreocupada com o objeto arquitetônico, é possível que este tenha sido realizada por algum profissional de seu escritório para uma obra de menor importância, possivelmente para algum amigo próximo. $\mathrm{O}$ desenho restante é um esboço para o projeto hidráulico da casa, não provendo mais informações de importância. É de se notar, porém, que o endere- 


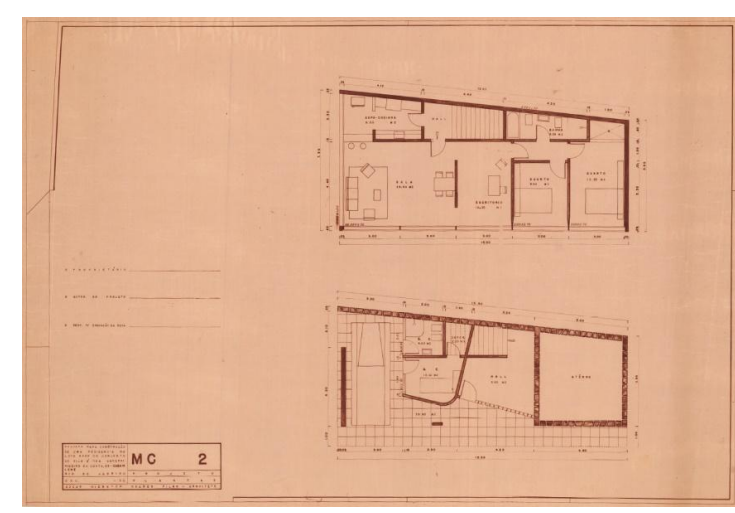

Figura 11 - Plantas da residência MC. Fonte: Acervo particular Philipp e Matthias Lamprecht ço da casa constante deste difere daqueles produzidos no escritório de arquitetura. Onde neste o endereço é o Lote XXXV da rua General Ribeiro da Costa, 28 casa 14, no outro ele aparece como na mesma rua, porém ao número 66, c. 14.

Se as desfigurações sofridas pelo projeto revisado durante a construção distanciam ainda mais a obra de seu criador, a primeira versão certamente deve ser incluída na lista de obras de Oscar Niemeyer.

Outras duas obras a serem incluídas pela primeira vez nesta lista compartilham características formais. O grupo escolar no bairro São Francisco, em Belo Horizonte (cuja data de projeto é desconhecida pelo autor), tal como a residência Vicente de Paula (1956), no Recife (AMORIM, 2007), apresentam a mesma cobertura inclinada sustentada por pilares inclinados com base no peitoril, resultando em um volume bastante dinâmico, sobre pilotis. Este esquema, que até então parecia ter sido utilizado apenas no grupo escolar de Diamantina, agora figura em cinco obras do arquiteto, reforçando sua livre estratégia projetual de prover novos usos a soluções formais consolidadas.

Sobre o grupo escolar, sabe-se que nele chegou a funcionar a Fundação Mineira de Arte, que foi criada em 1963 ao englobar a Universidade Mineira de Artes, em si fundada em 1954. Já a Escola da Artes Plásticas, subordinada à universidade, foi fun- dada em 1955, estabelecendo um curso preparatório em 1956, quando realizou seu primeiro vestibular. Sabendo-se que a primeira sede desta escola era instalada em um edifício antigo, à avenida Augusto de Lima (HISTÓRIA, s.d.), fica difícil determinar quando o projeto de Niemeyer foi construído - é possível, inclusive, que seja após 1957, o que o excluiria do recorte temporal desta pesquisa.

Já a residência pernambucana, que se localizava na praia de Boa Viagem e foi demolida (destino compartilhado pelo grupo mineiro) em 1989, lembrava bastante o projeto da residência Prudente de Morais Neto (1943 - 1949), tanto em planta quanto o corte, sendo que este último, indicativo de uma cobertura borboleta, era interrompido para integrar a solução a pouco discutida, permitindo ventilação cruzada nos quartos.

Igualmente ao Clube Caiçaras, um projeto para o Clube América (1956) parece chegar aos dias de hoje apenas por uma foto de sua maquete (figura 12). Neste caso, no entanto, uma legenda indicando a distribuição do programa sobre um terreno de um milhão de metros quadrados de frente à praia, no Recreio dos Bandeirantes, oferece detalhes do programa. Encabeçado pelo então presidente do clube, Giullite Coutinho, o projeto contaria ainda com a participação do engenheiro Fernando Souza para sua execução, noticiada como iminente: com a gleba assegurada mediante opção de compra já assi- 


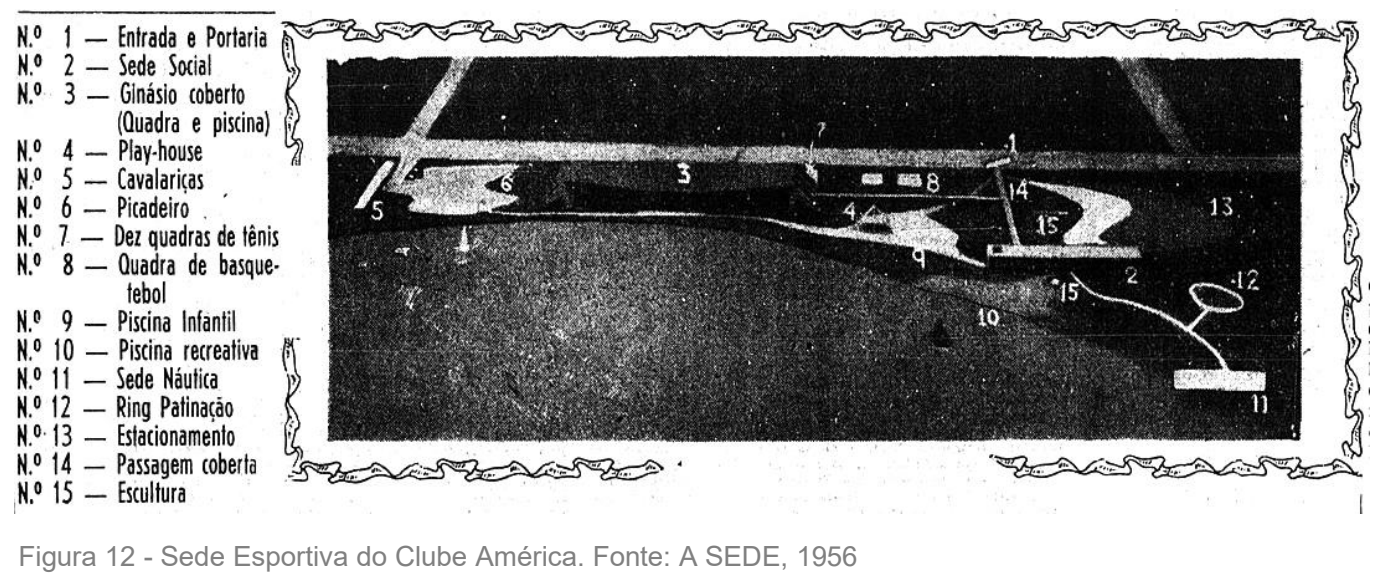

Figura 12 - Sede Esportiva do Clube América. Fonte: A SEDE, 1956

nada, previa-se o início das obras em 72 horas a partir da aprovação do plano por parte do conselho deliberativo do América(A SEDE, 1956).

Arquitetonicamente, o conjunto conta com duas grandes construções principais - um ginásio com piscina e vestiários, e a sede social. Entre estes, Oscar Niemeyer dispõe 'todos os esportes, da vela ao tênis, da patinação ao vôlei, ao hipismo, a natação [...]'. Pontes conectariam o clube ao mar, e mesmo um rink de patinação fora previsto.

Descobriu-se, se não o projeto (provavelmente perdido), o envolvimento do arquiteto com o cenário da peça Pedro Mico, de Antônio Calado e com direção de Paulo Francis. Mesmo que noticiada poucas vezes, a confirmação da realização da peça e consequentemente da cenografia ocorre com a coluna Teatro, de Henrique Oscar, no Diário de Notícias do dia 17 de setembro de 1957 (OS-
CAR, 1957). Na crítica, Henrique considera o cenário estilizadíssimo e muito bonito, apesar de totalmente inadequado para a peça, estando seu espírito em mais completo desacordo, não concorrendo de maneira alguma para a criação da atmosfera.

Sendo um par para a mais célebre colaboração com Vinícius de Morais, esta descoberta não mais isola como único trabalho de cenografia o barraco de Orfeu da Conceição.

Os dois últimos projetos de arquitetura aqui discutidos também são inéditos, sendo que nunca foram encontradas por este autor outras menções da Casa da Criança e do Hospital Sarah Kubitschek para além das duas matérias abaixo citadas. Uma pequena nota no Diário de Notícias do dia 27 de setembro de 1957 (BRAGA, 1957) menciona que o $27^{\circ}$ aniversário da instituição de caridade seria comemorado no local de sua futura sede à rua Fernandes Guimarães, em Botafogo - esta, seria um belo projeto 'de carona' de Oscar Niemeyer. Embora não tenha sido possível precisar o exato significado desta expressão, o envolvimento do arquiteto com Brasília sugere seu pouco envolvimento com a obra que se conclui já no final de 1958, como noticiado em grande matéria do Correio da Manhã (CASA, 1958) na qual a planta ('modernismo e sobriedade') é creditada pelo perfeito e independente funcionamento de três obras dentro de um só imóvel. 


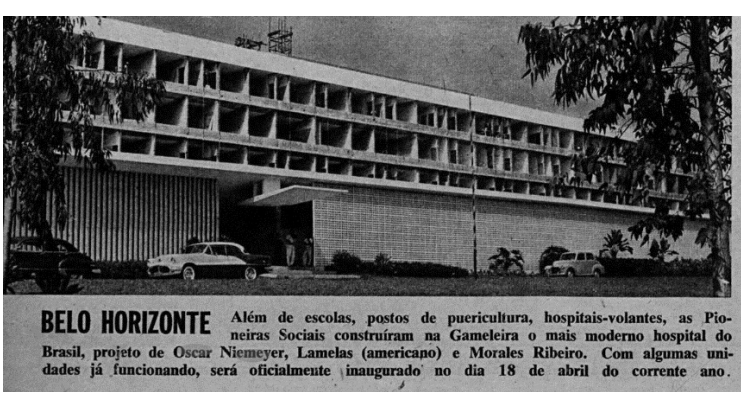

Figura 13 - Hospital Sarah Kubitschek. Fonte: TAVARES, 1960
Por fim, com uma ampla divulgação (HOSPITAL, 1958; EM, 1958; INAUGURA-SE, 1958; INAUGURAÇÃO, 1958), a inauguração do Hospital Sarah Kubitschek (Pioneiras Sociais) em Belo Horizonte (Gameleira) levanta o questionamento sobre por que um projeto tão vultuoso teria caído no esquecimento - a única outra citação a ele encontrado é de Danilo Macedo (MACEDO, 2002), como posto de saúde cuja autoria não fora comprovada. Uma imagem do hospital ainda em construção (figura 13) mostra um longo bloco horizontal, com fechamento térreo recuado em brise-soleils e elementos vazados, e uma marquise de acesso.

Se a tipologia segue a prática do arquiteto, o mesmo não pode ser dito de alguns detalhes - a projeção do bloco sob o 'pilotis' (que nem sequer conta com colunas aparentes) é proporcionalmente muito pequeno, e o suporte da marquise é demasiado grande, sendo excessivamente visível e comprometendo o efeito flutuante usualmente buscado por Oscar Niemeyer (como por exemplo no grupo escolar de Diamantina). Mais uma vez, a data sugere seu pouco envolvimento no projeto.

\section{Menções, trabalhos perdidos ou de autentici- dade duvidosa}

Aqui serão discutidos os casos mais complexos de projetos e obras que foram incluídas na lista ane$\mathrm{xa}$, sendo que a maior parte destes registram apenas uma única menção na literatura consultada.
Duas obras mineiras que insistentemente geram discussão em relação à participação de Oscar Niemeyer são o Palácio Mangabeiras, em Belo Horizonte (1951) e a Faculdade de Odontologia de Diamantina (1953). O primeiro chegou a servir de residência a Juscelino Kubitschek quando este era governador do estado. De acordo com Nauro Esteves (ESTEVES, 1989), tratava-se de uma casa 'muito engraçada' e que o arquiteto teria sido convidado a propor algumas adaptações.

Elucidando mais o caso (bastante criticado pela imprensa da época) existe uma resposta de Oscar $\mathrm{Ni}$ emeyer publicada em 26 de julho de 1951 (NIEMEYER, 1951) no Correio da Manhã, em que ele esclarece não se tratar a casa de projeto seu, ou mesmo de obra nova. Já em construção quando ele fora contratado para realizar outras obras no estado, a obra teria sido analisada pelo arquiteto, que resolveu apresentar um novo estudo. Este, preferido pela administração, foi, no entanto, recusado pela conveniência de uma simples reforma, visto que a estrutura e alvenaria já se encontravam prontos.

Sobre a faculdade de Diamantina, a pesquisa de Bruno Caldas deixou claro se tratar de uma situação similar com a descrita acima, na qual Niemeyer chegou a sugerir algumas modificações a um projeto já existente (CALDAS, 2014), sendo esses parcialmente acatados. Sem a potência de um trabalho autoral, este detalhe da história cabe melhor registrado na lista secundária. 
Outros dois edifícios que adentram a lista anexa são resultado de uma pesquisa dos arquitetos Celso Rayol e Marcos Sá ainda não publicada sobre edifícios modernos de Copacabana - três deles envolveriam o arquiteto, sendo um o já discutido Camargo, e outro localizado no Flamengo - o edifício José Tomás Nabuco. Segundo relato de parentes do cliente que nomeia o edifício, este teria sido uma encomenda familiar, para que os apartamentos (um por andar) fossem habitados por seus integrantes. Progressivamente, através da venda das unidades, o edifício acabou por ser convertido em unidades de escritórios, uso que mantém atualmente - processo este documentado em anúncios de venda que mencionam o arquiteto, especialmente no Diário de Notícias (COMPRA, 1957). Os desenhos do edifício não foram encontrados pelos pesquisadores, no entanto, sendo que não foi possível atestar com grau maior de certeza a autoria, ou mesmo o ano de projeto. Sabe-se que unidades já se encontravam à venda em 1957.

O terceiro edifício é o Pancreto, na Avenida Princesa Isabel. Sendo o envolvimento do arquiteto fruto de um único relato, e que ele aparenta ser um edifício moderno sem características que o destaquem como obra de Oscar Niemeyer, ele adentra a lista para que se registre a necessidade de investigação mais pormenorizada.

\section{Atribuições refutadas}

Embora não se pretenda comentar todos os casos em que a autoria do projeto tenha sido atribuída a Oscar Niemeyer, alguns casos merecem destaque por razão do erro ser amplamente difundido.

Um suposto projeto de Oscar Niemeyer para um hospital em Cataguases é mencionado em algumas fontes (AQUINO, 1950; MACEDO, 2002) e mesmo por alguns moradores locais, quando da visita deste autor à cidade. No entanto, se considerada a ampla divulgação dos projetos modernistas à época, e em se tratando do mais afamado arquiteto brasileiro, sua existência embasa questionamentos e mesmo suscita a hipótese de um engano relacionado a autoria do hospital projetado por Francisco Bolonha naquela cidade, exemplar projeto modernista de curta existência.

O posto de puericultura Jayme Gomes, no bairro Salgado Filho, consta da lista de obras cuja autoria não pode ser confirmada na pesquisa de Danilo Macedo (MACEDO, 2002). Subsequentemente, foram encontradas publicações de época que afirmam ser o projeto do arquiteto Hélio Ferreira Pinto. Conjuntamente com a manipulação pouco sofisticada de alguns elementos que, embora utilizados por Oscar Niemeyer, por via de regra eram formalmente tratados com maior propriedade, fica aqui refutada a atribuição ao arquiteto, pelo menos até que aconteçam novas descobertas. 
Outro erro comum e bastante persistente na imprensa local diz respeito à residência do antigo prefeito de Anápolis, Anapolino de Faria, nesta mesma cidade. Projetada e construída entre 1954 e 1957, a residência moderna não apresenta características da arquitetura de Oscar Niemeyer, especialmente em seus acabamentos. No entanto, fotografias de uma visita prestada ao prefeito por Juscelino Kubitschek, então acompanhado de Niemeyer (por razão dos trabalhos de Brasília), parecem indicar a autoria, que se reforça em uma carta de Sérgio Rodrigues para Marcos Zapp, onde o arquiteto é mencionado como autor do projeto (ALCANTARA, 2014).

Em 2017, a residência sediou a primeira mostra KZulo, uma mostra de arquitetura, design e paisagismo. Com ampla cobertura pela imprensa local, a relação de Oscar Niemeyer com o projeto foi ainda mais destacada, especialmente devido à participação do arquiteto Paulo Sérgio Niemeyer, seu sobrinho-bisneto, que possivelmente por desconhecimento, endossou a falsa autoria. Ademais das características arquitetônicas, de acordo com Regina Faria, sobrinha de Anapolino (ABREU, 201?), a casa é projeto de um arquiteto mineiro que chegou a participar da equipe de Oscar Niemeyer. $\mathrm{Na}$ mesma matéria, os arquitetos Elder Rocha Lima, que atua desde 1960 na cidade, e Marcílio Lemos, que trabalhou com Niemeyer na construção do Centro Cultural Oscar Niemeyer (em Goiânia), ca- tegoricamente negam a participação do arquiteto carioca.

Em agosto de 2019, foi publicado na revista Arquitextos, do portal Vitruvius, um artigo sobre a Usina de Juquiá que busca justamente atribuir a autoria do projeto da termoelétrica à Oscar Niemeyer (CORREA, 2019). Segundo o artigo, foi a filha do engenheiro Wellinghton Pinto Alves, responsável pela construção da usina entre 1957 e 1959, que 'descobriu' a autoria e busca, desde então, a certificação do projeto, junto à Fundação Oscar Niemeyer, ao Departamento de Águas e Energia Elétrica (DAEE) ou do Arquivo Público do Estado de São Paulo.

Inexiste, porém, menção à documentação que teria comprovado esta informação, levando à suposição de que, novamente, foi uma rápida leitura da arquitetura (que conta com o esquema de abóbadas conjugadas) que trouxe o nome do arquiteto à esta discussão particular. Quando se analisam os pormenores deste projeto, crescem os argumentos justamente para refutar a autoria: em 1957, Oscar Niemeyer já encontrava-se em outro momento de pensamento projetual, não mais utilizando, pelo menos da maneira que ocorre na usina, as abóbadas, cujas proporções deselegantes também estão em desacordo com o desenho do arquiteto. 
No caso da Usina de Juquiá, parece mais provável que o projeto seja de algum profissional contemporâneo a Niemeyer que tenha se apropriado de seu influente repertório: o projeto da Refinaria de Manguinhos (REFINARIA, 1955), de Firmino Saldanha (1906 - 1985) e Bina Fonyat (1918 - 1977), divide com a Usina seu esquema formal aplicado a um uso infraestrutural de tal forma que é possível levantar a hipótese de se tratar de obras dos mesmos arquitetos.

\section{Conclusões e trabalhos futuros}

Se a elaboração desta lista elucida diversos casos há muito pendentes na historiografia do trabalho de Oscar Niemeyer, ela também abre novos questionamentos e possíveis discussões, especialmente sobre as obras inéditas, mas não a elas limitadas. Uma lacuna bastante aparente do trabalho e que afeta diretamente a lista é o desconhecimento de algumas datas de projeto, visto que este dado poderia alterar a ordem dos itens. Ademais, é necessário um esforço substancial para conseguir propriamente ordenar os projetos e obras dentro de cada ano, mesmo com a ciência de que em alguns casos essa informação possa ter se perdido.

A criação de uma lista é uma atividade intrinsecamente generalizadora que pretende organizar uma grande quantidade de informação de forma que seja útil para aqueles que dela dispõe. As dificuldades encontradas nesse processo, se registradas nas observações e neste texto, claramente sugerem a criação de uma base de dados digital mais pormenorizada que aquela provida pela FON, na qual as fontes também possam ser consultadas. Visto que este trabalho convida outros pesquisadores a colaborarem com dados provenientes de pesquisas individuais e específicas sobre cada projeto e obra, é de interesse que esta base seja estabelecida o quanto antes.

O resultado desta pesquisa permite, pela primeira vez de forma razoavelmente precisa, visualizar o escopo do trabalho de Oscar Niemeyer e seus escritórios até sua ocupação com Brasília. No período de aproximadamente 23 anos que compõe o início de sua carreira, de sua prancheta saíram 138 projetos, sendo 212 edificações individuais das quais 108 chegaram a ser construídas. Destes 138,8 foram projetados para o exterior, 32 em Minas Gerais e 17 em São Paulo.

Ainda explorando os dados quantitativos daqui derivados, surpreende a importância do projeto do Centro Técnico de Aeronáutica, que o ocupa por mais de uma década. Com 32 projetos e 20 edificações construídas, este seria ultrapassado em vulto, se não em tamanho, apenas pelo Parque Ibirapuera. Nova relevância também deve ser atribuída ao trabalho de Oscar Niemeyer para o mercado imobiliário do Rio de Janeiro. Em São Paulo, onde a maior parte de sua obra se deu junto ao BNI, as particularidades de seus projetos são estudadas dentro das 
condições de trabalho da capital paulista como contraponto a sua prática habitual carioca. No entanto, com a adição à lista de vários projetos para o mercado praticamente desconhecidos - dentre eles o Parque Residencial Fonte da Saúde, o Edifício João Ernesto, os edifícios Gloriamar e Poços de Caldas e mesmo o Camargo - fica constatado que existem fortes paralelos entre a atuação do arquiteto frente a esse tipo de encomenda também em sua cidade natal.

Em relação ao fim da lista, este se configura não como corte, mas sim como um rasgo disforme dada contradição entre um claro recorte de estudo e a corrente realidade de produção do escritório de Oscar Niemeyer. Considerando o ritmo de trabalho acelerado que existe nos três últimos anos da década de 1950, juntamente com o caráter menos detalhado de sua produção a partir de 1960 e o determinante peso de seu escritório nos últimos 10 anos de produção, ficam claras não apenas a dimensão do desafio proposto pela continuidade da lista, mas também a incerteza da possibilidade de finalizá-la de maneira tão certa quanto ela começa. Tais desafios, no entanto, apenas corroboram a importância da elaboração de uma lista completa de projetos e obras que possa, através da apresentação de numerosos e minuciosos dados, amparar as muitas pesquisas que ainda são necessárias para melhor compreender tão vasta e variada obra.

\section{Referências}

A SEDE campestre do do América. Correio da Manhã. Rio de Janeiro, 5 de fevereiro de $19562^{\circ}$ caderno p.1.

A SEMANA do livro brasileiro em Montevidéo. Correio da Manhã. Rio de Janeiro, 15 de outubro de 1939 p.5.

ABREU, S. Outro projeto do arquiteto? O Popular. Anápolis, 201? p.?. Disponível em: http://casaanapolino.blogspot.com/2014/07/historia-e-projeto-dacasa.html. Acesso em: 09 mar. 2020.

ALCANTARA, A. Casa projetada por Oscar Niemeyer com móveis de Sergio Rodrigues. Casa Abril, 2014. Disponível em: https://casa.abril.com.br/casas-apartamentos/casa-projetada-por-oscar-niemeyer-com-moveis-de-sergio-rodrigues/. Acesso em: 09 mar. 2020.

AMORIM, L. Obtuário Arquitetônico. Pernambuco Modernista. Laboratório de estudos avançados em arquitetura da UFPE: Recife, 2017.

ANIVERSÁRIO do clube de aeronáutica. Correio da Manhã. Rio de Janeiro, 5 ed agosto de $19541^{\circ}$ caderno p.7. 
APARTAMENTOS de luxo prontos para habitação Correio da Manhã. Rio de Janeiro, 4 de dezembro deo $19553^{\circ}$ caderno p.3.

AQUINO, F. O Museu de Cataguazes. Diário de Notícias. Rio de Janeiro, 5 de fevereiro de 1950 $4^{\mathrm{a}}$ seção p.3.

ARCHITECTURE d'Aujourd'Hui, Paris, no. 42/43, Agosto 1952.

BARATA, M. Vida das Artes. Notícias. Diário de Notícias. Rio de Janeiro, 24 de março de 1956a seção 2 p.2.

BARATA, M. Vida das Artes. Jardins de Perry em Berlim. Diário de Notícias. Rio de Janeiro, 9 de março de 1956b seção 2 p.2.

BOTEY, J. M. Oscar Niemeyer. Obras y proyectos. Barcelona: editoda Gustavo Gili, 1996.

BRAGA, R. Notas. Diário de Notícias. Rio de Janeiro, 27 de setembro de $19571^{a}$ seção p.2.

CALDAS, B. T. Velho Tejuco Moderno A presença da arquitetura de Oscar Niemeyer em Diamantina. Dissertação junto à FAU-UFRJ. Rio de Janeiro, 2014.
CASA da criança educa do berço à maioridade Correio da Manhã. Rio de Janeiro, 10 de outubro de $19581^{\circ}$ caderno p.3.

CHATEAUBRIAND, A. O Homem Trágico. Correio da Manhã. Rio de Janeiro, 21 de novembro de $19522^{\circ}$ caderno p. 2 .

CIIC. Correio da Manhã. Rio de Janeiro, 20 de janeiro de $19553^{\circ}$ caderno p.13.

COMPRA e venda de imóveis. Flamengo. Diário de Notícias. Rio de Janeiro, 5 de maio de $19577^{a}$ seção p1.

CORREA, S. Wellinghton Pinto Alves e Oscar Niemeyer. Construção e ruína da Usina de Juquiá no Vale do Ribeira. Minha Cidade, São Paulo, ano 20, n. 229.02, Vitruvius, agosto de 2019. Disponível em: https://www.vitruvius.com.br/revistas/read/minhacidade/20.229/7444. Acesso em: 09 mar. 2020.

CLUB Sportivo. Revista da Directoria de Engenharia. Prefeitura do Districto Federal. Ano III, número 14, Janeiro. Rio de Janeiro, 1935.

DO MINISTÉRIO da Educação ao conjunto João Ernesto. Diário de Notícias. Rio de Janeiro, 15 de junho de $19523^{\circ}$ caderno p.17. 
EM Belo Horizonte, um dos mais modernos ambulatórios do país. Correio da Manhã. Rio de Janeiro, 20 de novembro de $19581^{\circ}$ caderno p.4.

ESTEVES, N. Depoimento. Programa de História Oral. Arquivo Público do Distrito Federal: Brasília,1989.

ESTÚDIOS e auditórios. Diário de Pernambuco. Recife, $1^{\circ}$ de abril de 1951 p.29.

EXPOSIÇÃO de Livros Norte-Americanos Modernos. Jornal do Commércio. Rio de Janeirio, 6 de agosto de 1939a p.12.

EXPOSIÇÃO do Livro Norte Americano Moderno. Diário Carioca. Rio de Janeiro, 11 de agosto de 1939b p.11.

FUNDAÇÃO Oscar Niemeyer. Relação em ordem cronológica das obras do arquiteto, segundo informações da Fundação Oscar Niemeyer. Rio de Janeiro, s.d.

HISTÓRIA. Escola de Design da Universidade do Estado de Minas Gerais. S.d. Disponível em: http://ed.uemg.br/sobre-a-ed/historia/. Acesso 09 mar. 2020
HOSPITAL Sarah Kubitschek. Correio da Manhã, Rio de Janeiro, 24 de agosto de $19582^{\circ}$ caderno p.7.

INAUGURAÇÃO de hospital em Belo Horizonte. Jornal do Brasil. Rio de Janeiro, 22 de novembro de $19581^{\circ}$ caderno p.6.

INAUGURA-SE em Minas ambulatório das 'Pioneiras'. Jornal do Commércio. Rio de Janeiro, 22 de novembro de 1958 p.2.

LEAL, D. Oscar Niemeyer e o mercado imobiliário de São Paulo na década de 1950: o escritório satélite sob direção de Carlos Lemos e os edifícios encomendados belo Banco Nacional Imobiliário. Campinas: Dissertação junto ao departamento de história da UNICAMP, 2003.

LOURES, M. Juiz de Fora em fragmentos. Tribuna de Minas, 27 de janeiro de 2013. Disponível em: https://tribunademinas.com.br/noticias/cultura/27-012013/juiz-de-fora-em-fragmentos.html. Acesso em: 09 mar. 2020.

MACEDO, D. M. Da Matéria à Invenção: a obra de Oscar Niemeyer em Minas Gerais 1938-1955. Belo Horizonte: Dissertação junto à Faculdade de Arquitetura da UFMG, 2002. 
MAURÍCIO, J. Artes Plásticas. Atualidades. Oscar Niemeyer. Correio da Manhã. Rio de Janeiro, $1^{\circ}$ de abril de $19551^{\circ}$ caderno p.10.

MORAES, M. Concurso 'Municípios brasileiros de maior progresso' - menção honrosa: Oswaldo Cruz. O Cruzeiro. Rio de Janeiro, 16 de fevereiro de 1957 p.45.

MINISTÉRIO da Educação e Saúde Pública. Exposição do Livro Brasileiro em Montevideo: catálogo. Serviço Gráfico do Ministério da Educação: Rio de Janeiro, 1939.

MOMA. Brazil Builds. New York, 1943.

NIEMEYER, O. A construção das Mangabeiras. Correio da Manhã. Rio de Janeiro, 26 de julho de $19511^{\circ}$ caderno p.2.

NIEMEYER, O. Projeto para construção de uma residência no lote XXXV do conjunto de vila à rua General Ribeiro da Costa, 28 casa 14 Leme, Rio de Janeiro. Rio de Janeiro, c.1955. Arquivo particular de Philipp e Matthias Lamprecht.

NIEMEYER progetou o Botafogo de amanhã. Correio da Manhã. Rio de Janeiro, 9 de novembro de $19522^{\circ}$ caderno p. 1
O EDIFÍCIO da Rádio Tamandaré à Rua do Imperador. Diário de Pernambuco. Recife, 11 de maio de 1950 p.4.

O INSTITUTO de Previdêcia do Estado do Rio Grande do Sul. IPE.RS, s.d. Disponível em: http:// www.ipe.rs.gov.br/80anos/conteudo/339. Acesso em: 09 mar. 2020.

O LIVRO Brasileiro em Montevidéu. Diário Carioca. Rio de Janeiro, 31 de outubro de 1939 p.6.

O PROBLEMA de morar. Rio edição 161. Rio de Janeiro, 1952 p.30.

OSCAR, H. Teatro. O espetáculo do TNC no República. Diário de Notícias. Rio de Janeiro, 17 de setembro de $19571^{a}$ seção p.16.

\section{PAPADAKI, S. The Work of Oscar Niemeyer.} Nova lorque: Reinhold, 1950.

PAPADAKI, S. Oscar Niemeyer: Works in Progress. Nova lorque: Reynhold, 1956.

PARQUE Residencial Fonte da Saúde. Diário de Notícias. Rio de Janeiro, 29 de outubro de 1952 p.5. 
PUBLICAÇÃO do Archivo de Floriano Peixoto. Correio Paulistano. São Paulo, 23 de abril de 1939 p.23.

RECIFE. Prefeitura Municipal. Lei municipal número 951 de 31 de agosto de 1950. Isenta edifício de impostos e taxas, conforme menciona. Disponível em: https://leismunicipais.com.br/a/pe/r/recife/lei-ordinaria/1950/95/951/lei-ordinaria-n-9511950-isenta-edificio-de-impostos-e-taxas-conforme-menciona. Acesso em: 09 mar. 2020.

REFINARIA de Manguinhos. Módulo Brasil Arquitetura. Rio de Janeiro, dezembro de 1955.

SEGRE, R. BARKI, J. Niemeyer Jovem: amor à linha reta. Projeto Design edição 345. Arcoweb: São Paulo, 2008. Disponível em: https://www.arcoweb.com.br/projetodesign/artigos/artigo-niemeyer-jovem-o-amor-a-linha-reta-01-11-2008. Acesso em: 09 mar. 2020.

SERÁ construído no Brasil o maior teatro do mundo. O Dia. Curitiba, 24 de novembro de 1951 p.7.

SIMONE, S. FRANCO, F. Posto de puericultura de Rancharia-SP: a desaparecida obra caipira de Oscar Niemeyer. Cadernos da história da ciência, vol.13 n.2. Instituto Butantan: São Paulo, 2017. Disponível em: http://ojs.butantan.gov.br/in-

\section{dex.php/}

chcib/article/view/126/113. Acesso em: 09 mar. 2020.

TAVARES, M. Dona Sarah caiu do céu. Manchete no.414. Rio de Janeiro, 26 de março de 1960.

WELTER, V. Tremaine Houses: one family's patronage of domestic architecture in midcentury America. Getty Research Institute: Los Angeles, 2019.

XAVIER, A. MIZOGUCHI, I. Arquitetura Moderna em Porto Alegre. Universidade Federal do Rio Grande do Sul: Porto Alegre, 1987. 